REVISTA ANDALUZA DE ANTROPOLOGÍA

NÚMERO 15: ACTIVIDADES TURÍSTICAS, CIUDAD Y PATRIMONIO CULTURAL: MIRADAS CRÍTICAS. TOURIST ACTIVITIES, CITY AND CULTURAL HERITAGE: CRITICAL GLANCES

SEPTIEMBRE DE 2018

ISSN 2174-6796

[pp. 47-73]

http://dx.doi.org/10.12795/RAA.2018.15.03

\title{
SUDDENLY LAST SUMMER: HOW THE TOURIST TSUNAMI HIT LISBON
}

Daniel Malet Calvo.

Centro de Investigação e Estudos de Sociologia (CIES-IUL)

Manuel Joao Ramos.

CEI-IUL Centro de Estudos Internacionais (CEI-IUL)

Instituto Universitário de Lisboa (ISCTE-IUL)

\section{Resumen.}

En el presente artículo fijamos nuestra atención en la capital de Portugal, Lisboa, y su reciente proceso de turistificación, que ha forzado a una revisión colectiva de la identidad de la ciudad y sus narrativas patrimoniales, para encajar los crecientes contrastes entre marginalidad y centralidad, circulación y calma, abandono y atención pública, indigencia y afluencia, spleen y euforia. Después de introducir nuestro foco teórico en el problema de los "comunales urbanos" y de presentar nuestra metodología cualitativa, pasamos a describir el proceso histórico que ha conducido a la transformación de Lisboa: desde el mega-evento de la Expo'98 cuando Lisboa era todavía un destino turístico periférico, hasta la presente economía urbana, especializada en el turismo ylos servicios. Vamos a centrarnos especialmente en los proyectos y políticas implantadas "desde arriba" durante aquellos años y en la crisis financiera de 2008, usada para liberalizar varios aspectos de la economía. 


\title{
Palabras clave.
}

Turistificación, Gentrificación, Mega-Eventos, Comunales urbanos, Antropología Gráfica.

\begin{abstract}
.
In this paper, we focus our attention in Portugal's capital city, Lisbon, and in the recent process of its touristification, which is forcing a collective revision of the city's identity and its patrimonial narratives, to make sense of the growing contrasts between marginality and centrality, circulation and calm, abandonment and limelight, indigence and affluence, spleen and euphoria. After introducing our theoretical focus on the problem of "urban commons" and the qualitative methodology used in the article, we describe the historical process that led to the transformation of Lisbon: from the Expo'98 megaevent when Lisbon was a peripheral tourism destiny, to the present urban economy that is specialized in tourism and services. We will focus especially in the top-down projects and policies developed during those years and the use of 2008 financial crisis to liberalize many aspects of economy.
\end{abstract}

\section{Keywords.}

Touristification, Gentrification, Mega-Events, Urban Commons, Graphic Anthropology.

\section{INTRODUCTION}

In her seminal book Governing the Commons, political scientist Elinor Ostrom identifies three overarching and rather pessimistic models that together have decisively shaped academic discussion and political decision-making in a variety of societal areas: Garrett Hardin's “tragedy of the commons” (Hardin, 1968) offers a gloomy reading of how environmental degradation results from free-ridder individuals' abuse of scarce common resources; Robyn M. Dawes later formalised Hardin's' proposal in his "prisoners' dilemma, a non-cooperative game plan that further highlights the paradox detected by Hardin in showing that individual rational strategies lead to collectively irrational outcomes (Dawes, 1973); Mancur Olson's theory of collective action posits that rational individual self-interest cannot voluntarily generate a collective benefit of common goods beyond small groups or without external coercion (Olson, 1965). Ostrom's own view is a cautiously optimistic one: she doubts the power and virtue of the static metaphor implied in the three models as an intellectual trap that doesn't allow for a deep understanding of the varieties and possibilities of self-organised collective action and of the multiple limitations faced by external intervention; she focuses instead on an 
empirical and comparative interpretation of common property rights' institutions based on pre-existent collective contracts, thus countering the fixedness of theoretical models with a fluid analysis of institutional networks.

Following Ostrom's lead, a number of authors have been significantly extending the scope of the concept of commons beyond its original limited setting, that of traditional collective property and management of forests, fisheries and grazing lands. Recent analyses of environmental pollution, urbanism, digital networks, academic production, cookery, fashion, justice and even political action highlight the great relevance and range of a field of study that was earlier thought to be but an interstitial and marginal field of collective human action. In the specific field of urban studies, however, a number of difficulties arise when the commons literature is brought in as a research tool. In particular, when we consider critical reshaping situations such as those affecting a city's identity, heritage and demographics, be it in the wake of natural disasters, violent conflicts or - as in the present study - intense touristification, we must acknowledge that we are dealing with an immensely complex and overlapping field, where the boundaries between private, public and common, on the one hand, and those between object and subject, individuality and massification, on the other, bear little resemblance with the cases from which Hardin or Ostrom derived their analyses.

Even if contemporary contemporary cities can be characterised as collectively experienced communal spaces and knowledge systems, its ownership and heritage rights transcend national and local rules, privileges and demands. Under the auspices of neoliberal touristification, they became central and most profitable spaces where private interests concentrate today in order to circulate and accumulate capital (Rogers, 2017), particularly when they become prey to the speculative practices of international investment corporations concerning urban land values (with the consent and partnership of public authorities; see Weber, 2010). Closely related with these complex financial operations, frequently based in offshore fiscal havens, national governments and local lobbies favour the organisation of highly-promoted worldwide cultural and sportive events, and the construction of leisure attractions and heritage sites, a process that geometrically fostered the development of a global-local tourism industry (Roche, 1992). The latter may thus be considered one of the most sophisticated and ravaging contemporary forms of capitalism, contributing directly to increase economic inequalities among locals, the geographical displacement of people through processes of gentrification and the degradation of previously socially-grounded institutions (Cócola-Gant, 2018). In this perspective, neoliberal touristification clearly seems to be a perfect example of a "tragedy of the commons", in the sense that unregulated and speculative private gain directly leads to unremitting, irreversible and unsustainable degradation of the scarce common good that is the city. 
As noted by Christian Borch and Martin Kornberger (2015) the uncritical application of the commons literature to the urban contexts can be problematic. Most city spaces should not be considered a subtractive resource as in the "tragedy of the commons" metaphor: the over-use of one individual doesn't reduce other people's benefit (except for specific cases such as roads). On the contrary, urban value relies mostly on a high demand over the city resources, favouring crowd circulation, relationality and ambiances of leisure and consumption for as many people as possible: "in fact, consuming the city is nothing but the most subtle form of its production" (Borch and Kornberger, 2015:7). In fact, a pre-condition for the workings of the gentrification process (the so-called "marginal gentrification", the first-phase of any gentrification process; see Rose, 1984), and for the growing of creative industries and the knowledge economy is the creation of stimulating urban ambiances. Gathering as many (different) people as possible sharing ideas and senses, working together and collaborating, walking and consuming is paramount to the success of contemporary urban economies. Density, circulation, stimulus and diversity are the cornerstone of urban life and value, as also stressed by classic urban authors suchs as Georg Simmel, Robert Ezra Park, Jane Jacobs or Richard Sennett. Unfortunately, under the conditions of neo-liberalism, commonly-created value such as the urban ambiance of a city is captured by the logic of capital and finally is withdrawn as a common resource.

Methodology

Following this line of thought, we develop in the present article an historical analysis of Lisbon's processes of place construction through the last three decades, focusing especially in the top-down efforts of national and municipal government to build an internationally-recognized brand. Our methodology consisted in the analysis of three major events that contributed to change Lisbon's urban economy and launch the city as an attractive destination both to holidays (and sometimes to stay) and to invest. The role of 2008's financial crisis in accelerating and consolidating these processes will also be considered, understanding that was cleverly used by public authorities as the only way to face the crisis. Promotional materials of those events, journalism pieces and secondary sources were analysed, along with other bibliography information devoted to understand similar processes such as the case of Barcelona (Spain), which was clearly the "model" that inspired Lisbon's mutations, as we will see later.

The particularity of Lisbon's case in a landscape of a growingly-touristified European cities deserves not only an historical and political analysis but also a socio-cultural scrutiny around specific and micro-local observations, which the authors carried out, especially in touristified neighborhoods. Therefore, in this article we endorsed the classic inductive methodologies associated to the empirical and naturalistic fieldwork traditions in anthropology and in sociology (Radcliffe-Brown, 1965; Blumer, 1969) . The observational part of our methodology was grounded in intensive field research 
following the contemporary approaches used to experience and perceive the uses and senses of urban settings (Lofland \& Lofland, 1995; Hammersley and Atkinson, 2007). As part of this endeavour, and adhering to the path suggested by Tim Ingold (2007, 2013: 128) and Andrew Causey (2017: 25ff) in respect to valuing knowledge gained during fieldwork as a process of attention that goes beyond and frequently overrides abstract deductive reasoning, we made extensive use of field notebooks but also of field sketches. We opted to share some of these in as an annex to the article, as visual, and forcefully subjective, witnesses to our perceived experience of touristified Lisbon.

\section{HOW LISBON WAS “BRANDED”: THE EXPO’98}

The average Lisbon dweller is today awkwardly trying to grasp a strange new reality: the city has suddenly and unexpectedly become an international attraction. AirBnBing, tuktuk touring, fast-paced urban rehabilitation, street pedestrianizing, babelic chattering in new jazzy cafés and restaurants, skyrocketing real-estate prices, and world-famous new residents (Madonna, John Malkovich, Scarlett Johansson among others) are the new talk of the town. These novelties have coincided with the end of a brief but very frugal period of economic hardship and social breakdown (2010-2015), ${ }^{1}$ with national sovereignty ebbing away in the face of impending state bankruptcy and the governing institutions humiliatingly bowing to an "austerity programme" imposed by a Troika executive (a meta-governing consortium composed of technocratic inspectors from the International Monetary Fund, the World Bank and the European Central Bank). The Portuguese seem to have woken up from a collective nightmare with a feeling of apparent relief fuelled by an official "austerity has ended" mantra.

Lisbon is the same old Lisbon, but it doesn't look and feel the same anymore: it's talked about, cherished, envied, desired, visited. A historical centre that has lain semi-abandoned and ignored for decades has suddenly been taken over by a new service economy, its buildings renovated, its traffic tamed, its riverfront beautified. What the Council and the service industry hadn't cared to do for the ageing Lisboners, they have done it for the foreign newcomers, deepening a sense of divestment that is particularly poignant among the more fragile sectors of the city's population. It's not that this momentous change in the collective imaginary wasn't wished for or that the political and financial elites hadn't laboured to make it happen, but the general take of the population seems to be one of utter surprise, incomprehension and alienation. A very recent (and internationally misunderstood) sketch by a local comedian, broadcast at the start of the latest Eurovision Song Festival, hosted by the city, perfectly expressed this collective feeling: parodying

1. Mixing emergency taxes, salary cuts, sharp rises in unemployment and emigration. See Carmo et al., 2015. 
Richard Attenborough's murmur in his famous nature exploration documentaries, the comedian presented the city's inhabitants to a worldwide audience as if they were an unknown exotic animal species living in a remote island paradise; the sketch was much criticized by the British media for mocking one of their national celebrities, ${ }^{2}$ but it fittingly captured this collective experience of cognitive dissonance - Lisboners are feeling today much like the timid animal that pokes its head out of its lair only to be "discovered" by a naturalist's video camera.

Notwithstanding its dwellers' new state of mind, the fact is that - as mentioned - Lisbon's coming of age as a city devoted to tourism and to an urban economy focused on leisure and services was planned, prepared and wished for by the central and local authorities and by a cluster of national and international financial powers (Mendes, 2017: 486-487). A number of conjectural factors - such as the drop in Mediterranean tourism flows in the wake of the 2011 "Arab Spring" in the Maghreb, and the fear-mongering against "Islamic terrorists" and "refugees" in Western media that has driven the global tourist industry to search for more peaceful alternatives ${ }^{3}$ - may have accelerated this outcome, but the buildup of the process that has shaped the city into a consolidated brand in today's urban economic landscape surely pre-dates them. The "Oscars" of the tourist industry, the World Travel Awards, have repeatedly been awarded to the city over the last decade, making it one of the most desirable and publicised destinations in southern Europe. The Portuguese capital has been accumulating awards since 2009 in both the Europe's Leading City Break Destination and the Europe's Leading Cruise Destination categories, resulting in its finally being awarded the great prize: the World's Leading City Break Destination (2017). ${ }^{4}$ Obviously, such international relevance in the tourism sector can't be explained solely in terms of the city's substantive qualities; therefore, in the next few lines we will

2. The sketch was aired on Richard Attenborough's $92^{\text {nd }}$ birthday, an unhappy coincidence which added to the British media’s outrage(https://www.express.co.uk/showbiz/tv-radio/956971/Eurovision-2018-Attenburger-Sir-David-Attenborough-Planet-Portugal-BBC-Scott-Mills-Rylan).

3. Portugal's geographical position and its struggling economy "sheltered" the country from the recent waves of East-West and South-North Mediterranean migration. Reaching Portuguese international waters from Northern Africa is very perilous for small vessels, given the prevailing southern direction of the Atlantic "Portugal Current" system; however, although the Portuguese authorities and NGOs profess unambiguous support for the European resettlement programme (directed at dealing with irregular migrants and asylum-seekers) and for the $2015 \mathrm{EU}$ refugee quota scheme (to distribute refugees arriving in Greece and Italy), the reality is that the few asylum-seekers and refugees who arrive in the country end up leaving for other Schengen destinations after a while - they tend to be relocated (i.e., isolated) in small towns far from the main urban centres, without any social ties or work opportunities. Costa and Teles (2017: 31) correlate the housing problems of the relocation programme with the exponential growth of tourism in Lisbon and Porto.

4. https://www.worldtravelawards.com/award-worlds-leading-city-break-destination-2017 (accessed $15 / 05 / 2018)$. 
endeavour to offer some clarification that may help understand how Lisbon has climbed the Mount Olympus of urban tourism in southern Europe.

It's helpful to remind the reader that the so-called Barcelona "model" has been for years a self-confessed, much-coveted benchmark for Lisbon's intellectual and political elites, an example that showcases the economic and financial benefits of converting an industrial city into an urban landscape of mass consumption. ${ }^{5}$ As was the case of Barcelona, the progressively sophisticated campaign for Lisbon's international promotion began with the design and implementation of the basic element required to generate mediatic attraction to a city: a brand image. Although the conditions for the possible transformation of Lisbon into a world-class destination were satisfied by the country's admittance into the European Union in 1986, the actual kick-off moment that turned it into an internationally attractive tourist destination came in 1994. Between February and December 1994, the city became the European Capital of Culture, an event which caused an unusually high occupation level in its then incipient hotel industry, fed by a stream of exhibitions, international conferences, and various high-level events such as concerts and meetings of the culture sector, filling up the capital's halls and auditoriums and peppering televised newscasts throughout Europe (Portelinha, 2009: 106). Of all the activities planned, perhaps the most fertile in terms of the city's promotion and external visibility - and the one that shaped the theatrical aesthetics of the "open set" that would occur again two decades later - was the makeshift urban intervention brought about by the municipality's Séptima Colina ("Seventh Hill") programme which, though marred by local controversy, received a number of welcoming international reviews. The Sétima Colina was basically a cosmetic intervention that subjected the façades of around 70 very run-down buildings in the city's most central neighborhoods to a quick cleaning and a coat of paint. These sudden bursts of vivid colors sprayed over scattered outside walls shockingly contrasted with the greyed and decaying environment of the city, as in a PostPop fantasy. The collapsing buildings were selected along a route that meandered through a series of neighborhoods that the municipal promoters desired to highlight during the exhibitions (from the Largo do Rato to the Cais do Sodré). These still constitute today some of the most visited areas of Lisbon by night: the Príncipe Real, the Bairro Alto and the Cais do Sodré.

This hasty, superficial and relatively low-budget "rehabilitation" programme also extended to the temporary clean-up of a few green areas and derelict public parks, and the addition of some public statuary and other elements of street furniture in an amateurish attempt to beautify the city before the arrival of foreign visitors. At heart,

5. Delgado, 2007; Capel, 2005; Lees et al., 2013, offer important critical analyses for the understanding of this process, from both the anthropological and the geographical perspectives, providing insightful and integrated studies of the ways political institutions, cultural and leisure industries and official public discourses shift and adapt to novel production and consumption models. 
this programme of radical façadism caused a small stream of negative reactions in the more elitist local press, and irked a good number of academics and intellectuals (Da Costa Holton, 2003: 186-187). The Sétima Colina surgical operation - and particularly the controversial installation of extra-large vinyl panels with nude photographs covering buildings that were in such poor condition that they couldn't even be painted over ${ }^{6}-$ may be read as an apt metaphor for the contradictions and shortcomings that afflicted the city's management: the organisers' intention of passing the old historical centre off to an international audience as "authentic" and still unspoiled by contemporary rehabilitation procedures coupled with a sense of shame for the sorry decay of its real-estate, exposing the lack of a coherent and socially responsible urban policy.

It should be noted that two contrasting visions for the future of the city were battling each other at the time, in the public sphere as well as in the local government offices. On the one hand, certain events undertaken by the municipality resolutely sought the international promotion of Lisbon by showcasing its unique urbanism, as was the case of the Sétima Colina programme. On the other hand, a tentative model of cohesive rehabilitation called RECRIA (Regime Especial de Comparticipação na Recuperação de Imóveis) ${ }^{7}$ - was being carried out in certain neighbourhoods (some as central as the Bairro Alto); this scheme attempted to restore decayed buildings by preserving the outside layers and improving the conditions on the inside, and sought to protect the local social fabric by avoiding the rent increase and speculative developments that had impoverished local poor populations in central Lisbon. This programme and its sequels (REHABITA, RECRIPH, SOLARH; Madeira, 2009: 30-39), though under-financed and very bureaucratic, allowed a good number of low-income house owners to renovate households that were mainly inhabited by sitting tenants, especially in central districts (15\% of the total interventions were rehabilitations; detailed information about this scheme can be found in Madeira, 2009: 57-72). The difference between these old rents and the expected profit (the rent gap, see Slater, 2017: 120; and Less et al., 2013) is an important key to understanding the recent processes of eviction and gentrification happening in many central districts in the years since Lisbon has become a global object of desire for international real-estate capital.

Becoming European Capital of Culture had a remarkable impact on the international press, and Lisbon was acknowledged for the first time in decades as having some future touristic potential for international investors - its only claim to fame so far consisted in having temporarily harboured Northern European refugees; becoming a spy base during the Second World War; and later on, in the mid-nineteen seventies, serving as the locus

6. In some of the cases, also because landlords, fearful of possible future takeovers of the buildings by the Council, refused to authorise the intervention.

7. "Special Regime for the Reimbursement of Real-Estate Rehabilitation". 
of a romantic, non-violent Revolution. The closing ceremony was marked by the public announcement of a follow-up major event of global dimensions: the Lisbon Universal Exhibition of 1998 (or Expo'98). Projected in the final period of the European Union's adjustment and integration programmes that endowed the Portuguese government with long-term low interest rates subsidies, Expo' 98 would become the greatest event the city had experienced in the contemporary era and an essential key to understanding modern Lisbon (Ferreira, 2006: 441-444). Moreover, for the more educated population, it embodied the reaction of the new democratic regime to a previous event that had been staged by the Estado Novo (the authoritarian and corporatist regime installed in 1926 in the wake of the crisis of the First Republic): that of the Exposição do Mundo Português ("Exhibition of the Portuguese World") in 1940. This is not the space to expand on that key symbolic event; suffice to say that, unlike Expo' 98 , it was a profoundly myopic manifestation, almost touching on the absurd. Opening at a time when the Wehrmacht had already routed the British and French armies, and when Nazi Germany and Fascist Italy had completed the occupation of most of Europe, the old Exhibition was staged as a commemoration of the $800^{\text {th }}$ anniversary of Portugal's foundation and the $300^{\text {th }}$ anniversary of the restoration of its independence from Spain. It aimed to state the consolidation of the Estado Novo regime and its tight control over the colonial possessions; but the resulting message only expressed the regime's clear detachment from Europe's tragic condition and its neurotic self-guarding against modernisation ${ }^{8}$. Still, the Expo'98 organisers strove to keep and recycle a few key elements of the 1940 exhibition. The new exhibition coincided with, and benefited from, the workings of the Comissão Nacional para a Comemoração dos Descobrimentos Portugueses ("National Commission for the Commemoration of the Portuguese Discoveries"), a highly ideological set-up bent on celebrating the $500^{\text {th }}$ anniversary of Vasco da Gama’s arrival in Southern India and of Álvares Cabral's landing on Brazilian shores. Although its productions (books, exhibitions, documentary films) were suitably imbued with postcolonial political correctness, the Commission struck the same nostalgic and celebratory chord of previous similar initiatives (i.e., in the 1890s and the 1930s): a self-serving glorification of national identity through the topic of "cultural encounters" with a near-total disregard for its problematic aspects (religious intolerance, population massacres, slavery, etc.). It also resuscitated a previously sanitised view of racialism (the so-called "Luso-tropicalist" ideology) that, in the 1930s and 1940s, viewed

8. António de Oliveira Salazar, Prime Minister of Portugal from 1932 to 1968 and maximum representative of the Estado Novo, summarized this central political stance of the regime (and of its socio-cultural manifestations) in a famous public appearance in Portuguese national television in 1965. Reacting to the United Nations Security Council's decision that urged the Estado Novo to cease military operations against the guerrilla movements in the colonial possessions of Angola, Guiné-Bissau and Mozambique, he stated: "we fight without making a show and without alliances, proudly alone" ("combatemos sem espectáculo e sem alianças, orgulhosamente sós"). URL: https://www.youtube.com/watch?v=WjcNjph-rWE (accessed 20/05/2018). 
creolity as proof of the comparatively benign nature of Portuguese colonialism. Much of this ideological construct was put on display at the Expo'98 and was endlessly repeated in the national media. In fact, there is clear continuity between the 1940 Exposição do Mundo Português and Expo'98, both exhibiting the cultural heritage of Portugal as a maritime empire. In 1940, the Estado Novo regime renovated Restelo, an abandoned industrial suburb on the western riverfront holding high symbolic value (it was from here that Vasco da Gama departed on his journey to India in 1498), and built the Praça do Império ("Empire Square") as a celebration of Portugal's historical hold of its overseas possessions. Fifty-odd years later, under the cloak of a very similar panegyric discourse, a team of liberal technocrats set about renewing an equally disused industrial outskirt that mirrored Restelo to the east of the city.

Accordingly, the official motto of the event - "The Oceans, a heritage for the future" -, while touching upon an increasingly fashionable global narrative about environmental sustainability, offered to revisit and recycle the core of Portuguese national identity propaganda: the deeply noncritical pride in the maritime Discoveries of the fifteenth and sixteenth centuries found at the root of the global trading network, a self-aggrandising theme that has been used over and over since the late $19^{\text {th }}$ century by the political and intellectual elites and in popular culture (Power and Sidaway, 2005: 873-875). Unlike the 1994 European Capital of Culture, Expo'98 was a massive event: 155 countries were represented and more than 11 million people visited the site during the 132 days of the event. In addition, it involved an intensive housing programme for an emerging middle class and the construction of a series of infrastructures (the Pavilhão dos Oceanos, the Oceanário, the Pavilhão do Conhecimento, etc.), in an enclosure that was specially built for the occasion at a derelict post-industrial riverbank area somewhat distant from the inner city, upstream of the Tagus river estuary. Surrounded by the old and humble neighbourhoods of Moscavide, Prior Velho and Chelas and the suburban housing projects of Olivais and Portela, the Expo'98 area, known today as the Parque das Nações ("Park of Nations"), was conceived and built with its back to them, insulated by a train line and a series of speedways that socio-spatially segregated it from its immediate lower-class environment (Ferreira, 2004: 52-56). The Expo'98 celebrations also served as a pretext for bringing about a previously planned series of peri-urban interventions of great magnitude, which endowed the city with a few spectacular new infrastructures: the second bridge over the Tagus (the longest in Europe at the time), a giant mall bearing the name of the most famous among the Portuguese navigators (Vasco da Gama), a central train and bus station designed by the Spanish architect Santiago Calatrava and a new underground metro line (Linha vermelha) connecting the station to the city centre (today, the line has been extended to Lisbon airport). These infra-structural programmes were supplemented by extensive housing projects, hotels, auditoriums, green areas and a stream of modernist pavilions for each of the countries represented, one of which ended up hosting the Casino de Lisboa years later. 
The megalomaniac investment of state and municipal budgets in the many urban interventions that the event entailed (Cabral and Rato, 2005: 216-217) naturally fostered the enrichment of the great national and international fortunes of the construction industry. Lisbon gained a new urban node, even though its social and economic success was rather muted. The Parque das Nações is to this day but a peripheral area of the city, a clean and recently-built residential neighbourhood populated by upper-middle-class inhabitants that, against the early expectations of the promoters who had conceived it as a bucolic riverbank to placidly contemplate the large estuary of the Tagus River, fails to attract significant tourist flows (Gato, 2014). The relative marginality of the new Lisboa Oriental contrasts with the fate of another riverside district which has been reaping a remarkable success in its tourism projection: the area of Restelo-Belém, the westernmost neighbourhood of the city, at the opposite end of the Expo'98 area. There, the tourist encounters a series of iconic elements that project the expected image of the city's heritage: the monumental architecture from the era of the Discoveries (the Jerónimos Monastery and the Belém Tower), local fish restaurants and patisseries that sell the world-famous Belém custard pies and, finally, the contemporary Belém Cultural Center (CCB), housed in a building that was originally built to host the seat of the rotating presidency of the European Community in 1992.

The fear recurrently expressed by the Expo' 98 promoters at the planning stage was that it might become a "white elephant" paralleling the fate of Seville's Isla Cartuja (the locus of the Universal Exhibition of 1992). To avoid this, they sought their inspiration in the way Barcelona had managed to profit from the investment made for the XXV Summer Olympics (also in 1992), launching an international campaign aimed at touristifying and gentrifying both its historical centre and the new riverbank setting. Although today's Parque das Nações may pale in comparison with what Barcelona has attained, the same principle of marketization to attract the tourist masses applies in the case of Lisbon - to the point that the city has recently even managed to outgrow Barcelona's success (probably benefitting, too, from the political instability that the Catalan capital is enduring since the independence referendum of 2017).

\section{THE YEARS BEFORE THE STORM: THE BAIRRO ALTO AND THE EUROPEAN CHAMPIONSHIP OF 2004}

This brief compendium of major events that have shaped the new globalized concept of the Portuguese capital must necessarily include the $12^{\text {th }}$ edition of the UEFA European Football Championship in 2004 (Euro 2004), whose lasting contribution to the metamorphosis of Lisbon into a tourist destination was to portrait it as an immensely attractive urban space in terms of nightlife, especially in Bairro Alto, a small district in 
the western hills of the historical centre. Southern Portugal was already an established international tourist destination and the Algarve beach resorts and coastal towns, much like the Costa Brava in Spain, had gained a reputation for their long sunny seasons, cheap eating and nightly boozing, especially among the masses of low-budget British tourists. It was probably not a coincidence that it was the British football fans who first flooded the Bairro Alto bars - they were purportedly directed to the area by the Portuguese security agents and tourist operators on the advice of their British counterparts, as a preventive measure against hooliganism in the vicinity of the football stadiums. Contrary to the distinctly poor and marginal Alfama and Mouraria quarters on the slopes of the São Jorge castle, Bairro Alto has historically been a mixture of noblemen's palaces and thieves' lairs, where playwrights and fado singers, bourgeoisie and prostitutes would live cheek by jowl (Braga, 2013). Some years after the fall of the authoritarian regime in 1974, when the political revolutionary movement started to fade, Bairro Alto became a preferred spot for a cultured middle-class youth in search of edgy nocturnal entertainment in a markedly bohemian and tolerant environment, that still emanated an intensely local and secluded atmosphere, partly due to its urbanistic features (Carita, 1990; Balula, 2010: 4951). Progressively, it became the epicentre of the city's nascent alternative counterculture - a new development led by the gay movement -, the place to get high and dance, in a still very provincial city largely insulated from international culture consumerism (Cabêdo Sanchez and Martins, 2003: 250-251). Coveting the immense success of the 1980s Movida Madrileña, Lisbon's then councillor for culture (João Soares, the colourful son of the late Mário Soares) tried to replicate it by fostering the indiscriminate and unlicensed opening of new bars and nightclubs, and turning a blind eye to closing time regulations. Later, in the early 2000s, a new Mayor, the flamboyant Pedro Santana Lopes, ordered the pedestrianisation of a section of Bairro Alto and of the São Jorge’s Castle neighbourhood, on the opposing eastern hill - thus creating the infra-structural preparations to the district's new destiny: becoming the city's favourite nocturnal landscape.

Episodic violence was never a strange element to the Bairro Alto, from the nineteenthcentury rufias spoken of in the melancholic fados, to the clashes between the so-called "urban tribes" during the 1990s, the regular pickpocketing and the petty thievery targeting the alternative youth visiting from the well-off peripheries. In short, violence in Bairro Alto was often the product of a rather unusual coexistence of social classes in a vibrantly recreational urban environment blending diverse cultural influences and youth lifestyles. Expunging violence and insecurity in Bairro Alto became the main goal of the municipal authorities, who strove to endow the neighbourhood with attractive dynamic businesses and services, opening up to a newly formed, youthful consumer middle class. Together with a suddenly successful international tourism flow and the mass invasion of European university students participating in the Erasmus exchange programme, this middle class would come to extinguish the social and cultural heterogeneity that had characterised the Bairro Alto for centuries. 
At the time of the Séptima Colina operation and during the next decade it was still unthinkable for the Council to close its inner city area to car traffic, succeeding in making it more appealing to tourists. These being the "golden years", when access to leases and credit were immensely eased and the Portuguese collective dream of private car ownership was finally realized (nationwide, car owners/drivers increased tenfold in the period of 1985-95), driving and parking anywhere - including on every bit of sidewalk - was taken as an inalienable and uncontested right. Still, Bairro Alto was progressively opened up to the outside. During the Expo'98 the subway reached Chiado, the quarter's southern limit, connecting the neighbourhood to the rest of the city and, more importantly, to the population of the suburbs. ${ }^{9}$ Even before the 2004 European Championship, Bairro Alto's bohemian and alternative environment was already in crisis. Its narrow streets had become a fairly peaceful and secure, with police patrolling every night. The typical grocery stores and other small shops that catered to its resident population were progressively replaced by flashy boutiques, exotic antiquarians and avant-garde art galleries. Still, Euro 2004 marked the most decisive step towards the internationalisation of the district: crowds of enthusiasts from various nationalities followed in the footsteps of the British team's fans in their nightly escapades to the Bairro Alto's central area, where cheap small bars, clustered in a few streets, encouraged visitors to drink and party outdoors until the wee hours of the morning. From then on, the nocturnal disturbance enabled by the abovementioned liberal granting of permissions without proper inspection and licensing, started to cause recurrent conflicts of coexistence with the resident population. Every night until at least $5 \mathrm{am}$, a sea of young people would perform the same mass ritual of chatting, drinking, dancing, shouting, graffiting, peeing and vomiting on the streets. And every morning, the council's street cleaning personnel would wash away empty plastic cups, glass bottles, designer-drug capsule containers, urine, vomit and the odd needle littering every horizontal surface, to make the streets ready for the day's tourists and shoppers and the next night's ravers.

A crescendo of complaints - quite unprecedented, coming from a low-class and aged population that traditionally tended to endure abuse without a word - demanded action from the City Council. Somewhat reluctantly, the Council approved in 2008 a drastic Plano de Reabilitação Urbana ("Urban Rehabilitation Plan") for the neighbourhood (Costa, 2013: 12-14), under which bars and nightclubs couldn't (and still can't) stay open past 2am, with police patrols cracking down on after-hours street boozers. Shortly

9. Since the early 1980s, Lisbon had been losing its resident population in favour of the suburbs. In 1981, 807.937 people lived within the city administrative limits; by 2011 the resident population had dropped to 547.733, according to the Portuguese National Institute of Statistics (Instituto Nacional de Estatística, 2011). The decaying and unsanitary conditions of many of the city's buildings, the attraction of modern housing in the suburbs, together with easier access to credit for homeowners and car-owners, dictated this shift, although the "return to the inner city" by segments of younger middle-classes has partially occurred in the last decade (Rodrigues, 2010). 
afterwards, a new police station opened in the heart of Bairro Alto, and video surveillance cameras were installed. The local authorities then took advantage of the occasion to drive away "problematic" suburban youngsters - especially those of African origin, who were systematically targeted by the police in anti-drug operations - that tarnished the image the municipality now wanted the place to have. Little by little, the older bohemians and the hipsters moved from the classic Frágil (a bar-cum-nightclub that was the fulcrum of Lisbon's avant-garde and alternative nightlife in the 1980s) to Lux in the eastern riverfront, while the younger rappers, hip-hoppers and Afro-tuners chose Alcântara and Santos, in the western bank. As all traces of "alternativeness" were erased, a tamer and more sanitized version of the botelhã $0^{10}$ took over the district.

Today, Bairro Alto attracts incredibly large crowds and has become an intensivelyexploited area for nightlife, indistinguishable from its counterparts elsewhere in the world (see Chatterton \& Hollands, 2003); as its inhabitants vanish under the pressure generated by the long and noisy nights, the neighbourhood is taken over by charming new hostels and quaint short-rental apartments. Local associations rarefy and venues offering alternative cultural projects flounder, while the few remaining bars and restaurants from yesteryear acquire protected heritage status, dooming the area to the tragedy of anodyne homogeneity (Pavel 2014: 15).

In sum, the three events summarily described above laid the foundations for subsequent developments in terms of reception of visitors, stimulating the appearance and consolidation of economic sectors dedicated to tourism, and preparing the city to efficiently host large flows of visitors. The much-needed modernisation of its mobility and accessibility infra-structures, an electoral promise to its constituents that the City Council proudly kept, ended up benefiting tourists and tourist operators the most - be it the airport's expansion, the extension of subway lines, the new cruise terminal, the traffic-calming and parking-limitation measures, the pedestrianisation of large tracts of the riverfront, the rehabilitation of squares, gardens and parks, or even the displaying of multilingual signage in tourist-flooded areas. ${ }^{11}$ These international events were important pretexts (as they always tend to be) for both investing in urban reform and polishing up a glamorous branding image (Santos, 2000: 33-36) in order for the city to compete as a recognisable and appetising destination in the international market of mass tourism.

10. An expression adapted from the Spanish botellón that refers to the habit of sharing alcohol in bottles among friends in the street to avoid the high prices of local clubs. The practice is fueled by a late-night network of small groceries (usually managed by Pakistanis, Bangladeshis and Chinese) and tiny kiosks selling beer directly to the street.

11. On the other hand, numerous infrastructures are still underused: the stadiums built purposely for the 2004 European Championship left the majority of Portuguese clubs indebted for their very expensive maintenance (Marques Durão, 2011: 235-237), and the extensive public parks and avenues in Parque das Nações area are normally empty (the celebration of annual events such as Rock in Rio in the nearby Parque da Bela Vista has so far failed to act as an attractor for a more permanent usage of the green areas). 


\section{FROM THE FINANCIAL CRISIS OF 2008 TO THE HEGEMONY OF THE TOURIST ECONOMY}

A further key to grasp how and why Lisbon climbed the ranks of the top European tourist destinations was the ripple effect of the 2008 worldwide financial crisis. The then centreleft government led by the complex figure of José Sócrates Pinto de Sousa ${ }^{12}$ attempted to respond to the floundering of the fragile national financial system by offering a questionable boost focused on a ruinous programme of public investment in extensive infrastructural works (namely, road structures and public buildings) that completely wrecked the economy and nearly bankrupted the state's finances. The consequence was the demise of the "Sócrates" government and the European Union's imposed intervention of the abovementioned Troika in Portugal, managed by a centre-right coalition government led by Pedro Passos-Coelho (2011-2015), an apt yes-man who became the figurehead of the European Union's (neo)liberalising policies. At the same time as the austerity package was being forcibly applied ${ }^{13}$ under the supervision of the Troika, a series of legislative changes occurred that were instrumental in facilitating the expansion of the tourism and real-estate businesses. Lisbon's City Council, governed by the Socialist Party (with a comfortable majority at the Municipal Assembly), and fully aligned with the idea that investing in the tourism sector was the quickest way to fix the country's economy, created several incentive programmes for tourist-linked real-estate activities that strengthened the neoliberal managerialism of the city (Harvey, 1989; Tulumello, 2016: 132-134). The approval by the "Sócrates" government of a decree establishing a Regime Jurídico de Reabilitação Urbana ("Legal Regime of Urban Rehabilitation") in 2009 was an essential landmark to liberalise the housing sector, offering tax benefits to investors, facilitating

12. "Engenheiro Sócrates" is an unusually controversial character. The paradoxical way he is referred to (by title and first name, mixing respect and familiarity) hints at his exceptional status in the Portuguese public eye: according to the rather conservative and sexist Portuguese etiquette rules, big men are generally addressed by title and patronym, whereas big women, in a demeaning way, are called by their title and first name. In fact, only another national male figure is mentioned in the same manner: Marcelo Rebelo de Sousa ("Professor Marcelo"), the current president of the Republic, is a retired senior professor of Law, ex-journalist, ex-political commentator, ex-enfant terrible and eternal gossip queen of Lisbon's elite circles. "Engenheiro Sócrates", by contrast, is an extremely ambitious arriviste originating from the provincial petty bourgeoisie who has been involved in a never-ending stream of scandals - from acquiring his BA and MA through allegedly fraudulent means to standing accused of dozens of crimes in turbo-charged corruption cases. The ambiguities sensed in the personal life choices and public postures of these two figures seem to have fuelled a discrete homophobic labelling that the etiquette oddity underscores.

13. It is worth noting the comparatively benign and obedient way Portugal and Ireland dealt with the imposed austerity in this period, in clear contrast with the much more strident and conflicting Greek and Spanish cases. The immediate "reward" was a much more tolerant response from the ECOFIN and the $\mathrm{ECB}$, and consequently improved financial rating and better conditions in the repayment of the national sovereign debt. 
administrative procedures and stimulating the attraction of financial capital for real-estate activities. In addition, the coming into effect of the Estratégia de Reabilitação Urbana 2011-20 para Lisboa (“Urban Rehabilitation Strategy 2011-2024 for Lisbon") targeted the city as the object of rehabilitation financing schemes such as Reabilita Primeiro, Paga Depois ("Rehabilitate First, Pay Later"). Along the same lines, the central government approved a series of tax exemption programmes for the purchase and rehabilitation of buildings, with a view to attract foreign fortunes - Regime Fiscal para Residentes Não Habituais ("Fiscal Regime for Non-Habitual Residents") and Golden Visa Portugal - that turned the country into a privileged real-estate haven for international capital in times of crisis. According to the joint partnership Transparency International - Organised Crime and Corruption Reporting Project on Golden Visas, the almost total lack of fiscal control in the implementation of these real-estate tax exemption schemes has resulted in the regular laundering of international capital of dubious or criminal origin, mostly related to corruption, terrorism, drug trafficking and organized crime (Gines, 2018).

With the support of all these national and local financing programmes and under no obligation or incentive to offer housing for residents, investors and owners opted for realestate speculation, which had greatly intensified with the growth of Lisbon and Porto as tourist destinations. In addition to investor groups and various speculators, many middleand upper-class foreigners, answering the call of the "Lisbon brand", began acquiring housing in the city centre and elsewhere, either for renting out or living in (partially or full-time). In fact, the desired target of these policies were the waves of migrants from privileged countries looking for a "good life" (this trend has prompted the emergence of a specific genre, that of the "lifestyle migration literature"; for examples, see Janoschka and Hass, 2013 and Torkington et al., 2015): French pensioners and Polish Erasmus students, North-American surfers and Italian urban artists, Brazilian elite expats and Chinese mandarins, Dutch freelance graphic designers and New Zealand start-uppers. For all these groups and many others (i.e. people either looking for a transient life experience or expecting to establish themselves in a relatively accessible destination with a high standard of life), Lisbon has managed to respond with requisites unattainable in their country of origin (Benson \& O'Reilly, 2009: 610-611). The attraction of foreigners with greater purchasing power than the Portuguese (whose average salary does not exceed 800 euros per month) is essential to ensure the predatory consumption of real-estate and services that is ravaging Lisbon, perfectly matching the investors' expectations. The attraction of Lisbon for the international public other than recreational tourists has been also fuelled by global events such as the Web Summit, an annual technology conference hosted by the city since 2016, which brings together more than 70,000 attendees every year.

Another aspect of this demographic influx, and one that usually occupies less than a footnote in the official and non-official discourses about the "new Lisbon" success story, 
is the existence of immensely varied groups of migrant workers who guarantee, in the background and at the bottom end, the functioning of the urban system of production and consumption: Brazilian, Romanian and Senegalese masons building new hotels and luxury residences, Nepalese and Pakistanis cooking and waiting at the tables of fusionfood restaurants, and Bangladeshi and Chinese attending hundreds of convenience stores, among others. Occupying the lower part of this pyramid, along with young Portuguese precarious workers, they provide the enabling conditions that nowadays make Lisbon such a seductive space for leisure, residential tourism and urban consumption.

As we've seen in the previous sections, the increasing attractiveness of the Portuguese capital to a foreign public is rooted in policies that were planned and carried out by the Portuguese central government, in partnership with Lisbon's City Council, over the span of at least two decades; however, the present boom also owes much to the converging conjunctural effect of the financial crisis of 2008 and the disruptions that followed the Arab Spring (the instability in the Maghreb and the war in the Middle East) that are steering new waves of "Northerners" (including those coming from the "South") towards cheap, sunny and hitherto terrorist-free destinations.

An intervention that epitomises the present opening of the city to tourism in one of its most stigmatized and marginalized areas was carried out at the Intendente, a previously run-down square adjoining Avenida Almirante Reis and close to the most central historic neighbourhoods of the city. Praça do Intendente was for many decades one of the most notoriously marginal areas of the city, the preferred place for street prostitution and hard drugs. In 2011, Lisbon's Mayor, António Costa, now the country's Prime Minister, decided to move his official office from the traditional Paços do Concelho next to the Terreiro do Paço, to an old ceramics factory (Cerâmicas Viúva Lamego) located at the Intendente (the square was undergoing at the time an extensive "intervention" that involved pedestrianisation, new public furniture, and renovation of the adjacent buildings). It goes without saying that this symbolic presence immediately pushed marginal practices a couple of streets back; nevertheless, the sudden investment of large sums of public money in this neighbourhood also resulted in progressive but unstoppable real-estate reconversions, and an intensive gentrification process which replicated a model common to many other Iberian cities (Janoschka et al., 2014: 1239-1241). This apparently casuistic operation and shift of the siege of local power was in fact planned to coincide with the UNESCO's declaration of Fado as an intangible cultural heritage. This urban melancholic song is closely associated with both the nearby districts of Alfama and Mouraria, where Severa, the mythical founder of fado, lived and died. It only took a few years to totally transform the Praça do Intendente; in fact, this transformation was so intense that Lisboners find it hard to believe that this square, one of the most stigmatized and dangerous spots of Downtown Lisbon until six years ago, is now an internationally 
coveted area populated by foreign artists and vegan hipsters which harbours some of the city's most trendy cafés and bars (for classic examples of the speed with which gentrification functions in other global urban landscapes, see Caulfield, 1989 and Ley, 2003).

Meanwhile, in 2012, the then Minister of Territorial Planning Assunção Cristas approved the Nova Lei do Arrendamento Urbano (NRAU, "New Urban Renting Law"), which would finally facilitate evictions, terminating old rents, doing away with sitting tenants and favouring an exponential rise in the rent and purchase prices of real estate. Many small landlords as well as multi-owners and real-estate companies discovered that renting flats to tourists was an extraordinary business opportunity, magnified by the rapid expansion of internet platforms such as $\mathrm{AirBnB}{ }^{14}$, which facilitates online bookings and allows constant speculation with the rental price. In addition, landlords advertising on AirBnB escaped paying taxes until 2016 and, since then, they have only paid half of the taxes due if they placed the flat on the much less attractive permanent residence rental market. Thus, with express evictions made possible by the NRAU, temporary housing for tourists sprang everywhere in the central neighbourhoods, removing a large number of flats from the regular-rent housing market, a measure which in turn caused several spectacular rise waves both in the average price of rentals and in the property market. This "tourist gentrification" phenomenon (Gotham, 2005) has - according to the real-estate portal Imovirtual - caused a price increase of 26\% between 2016 and 2017 (with an accumulated $67 \%$ total increase since 2014). In December 2017, the rental price of the square meter in Lisbon was $€ 2.80$, which represents a rise of $36.92 \%$ in relation to December of the previous year (according to the housing price index measured by Idealista).

\section{THE LANDSCAPE AFTER THE BATTLE}

During the campaign for the 2017 local elections, the Socialist Party - in fact, a centrist outfit that tends to swing between social democracy and neoliberalism - was pressured by its unlikely supporting partners in the central government (the orthodox Partido

14. Lisbon is the second most profitable AirBnB host globally, earning a lump sum of 29 milion euros (https://www.dn.pt/dinheiro/interior/airbnb-proprietario-em-lisboa-faturou-29-milhoes-de-euros-8908534.html, accessed 21/05/2018). Another important online platform functioning like AirBnB is UNIPLACES, which also offers rooms and houses directed to higher education students for medium-term stays. The growing sector of international students represents the newest craze in the house-rental industry (about 70\% of rooms displayed in UNIPLACES are rented by foreigners). International students arrive in troves to the city, attracted by the widespread appeal of the "Lisbon brand" (as many other groups of foreigners) and by the success of Study in Lisbon, an internet platform created by the City Council in partnership with Lisbon's universities, a number of start-up enterprises, and the tourism public offices. The project aims at attracting foreign students to Portuguese higher education institutions, and new talents to the creative and industrial sectors. This strategy, shared by many global cities in the present stage of the contemporary urban system of production, has been termed by some authors "cognitive-cultural capitalism" (Scott, 2014). 
Comunista Português and the leftist Bloco de Esquerda) to negotiate a few palliative social reforms to mitigate the impact of an astounding wave of neoliberal policies handed down from the previous centre-right government and hitherto unchanged. Express evictions that were included in the 2012 NRAU were later limited, some 100 Councilowned flats were offered for social rent to low-income residents, and a new Lei de Base do Arrendamento ("Basic Law of House-Renting"), presently under discussion in the National Assembly, was issued. However, such initiatives come with notable delay, at a time when the unstoppable gentrification of the old centre is in full motion (as the more than 13,000 homes on offer at AirBnB indicate), and the great exodus of the poorer inhabitants from the city centre is a fait accompli. Every day, an average of 5.5 families are evicted in Portugal, doubling the 2013 ratio. This is happening mostly in Lisbon and Porto, according to the Banco Nacional do Arrendamento ("National House-Renting Agency"), and it is due to the citizens' lack of purchasing power to survive in the framework of a city whose supply and demand chain is being now at least partly decided by the global real-estate market. The Socialist Party, despite the hesitant social reforms that it is now being pressured to undertake, still considers tourism and real-estate development the life-buoys that can keep the country's finances afloat. The current government boasts about the new, lowered unemployment rate, a hollow triumph that totally dismisses the ultra-precarious, low-paid and self-employed nature of the job market. Lisbon's urban economy is growingly parasitised by the tourism and service industry, which gambles with temporary, highly flexible and underpaid work. Meanwhile, business schools are promoting productive, entrepreneurship-based logics whose fruits are to be quickly absorbed by world-class companies, while the bulk of the effort, work and creativity are lost in a likely unsustainable spiral of immediate utilitarianism.

As concerns the urban liveability of the city, mass tourism has been responsible for an intense overload of its infrastructures. In the last five years the number of vehicles rented by tourists has grown exponentially. Not only the usual rent-a-car fleets, but also a varied bunch of recreational-type transports, such as the Go-Car, the Segway, the shared and rented bicycles and electric scooters and, above all, the omnipresent tuk-tuks, now cram the steep and narrow streets of the city centre. As a consequence of the expansion of the latter, tourists manage to access even the remotest corners of the city, driven by young precários, who offer impromptu guided tours while transporting them around.

In addition to the myriad vehicles overloading the streets of the city centre and the heavy pedestrian traffic in the narrow sidewalks caused by the swarms of tourists, collective public transport has also been deeply affected by the new flow of visitors. During the increasingly long high season, the metro, bus and tram lines that connect the routes and sites most frequented by tourists tend to break down regularly, a situation that has led to unusually vociferous complaints by the native users. Lisbon is considered one of the fourteen world destinations with the highest risk of suffering an overloaded public 
infrastructure, according to the report "Coping with success. Managing overcrowding in tourism destinations" of the World Travel \& Tourism Council. According to this report, Lisbon is already in the same group as Barcelona, Cancun, Venice, Rome or Prague, and many points above Paris, Rio de Janeiro, New York or Rome.

In the last five years, the city has opened to the river on several fronts: a walkway now connects the renovated Praça de Comércio with Cais do Sodré, while at the foot of Alfama a cruise terminal has been built for monstrous ships ten times higher than the houses in the neighbourhood. An economy directly aimed at foreign visitors has been replacing traditional local commerce, transforming old groceries and cheap restaurants into cocktail bars, trendy restaurants and gastronomic spaces, a reconversion highlighted by the fact that Lisbon is the founder city of the Time-Out Market website. Mercado da Ribeira, the old food market by the river, has been colonised by a permanent fair of gourmet products, a row of restaurants and franchises selected by Time Out magazine which has proved a huge success among tourists. As a consequence of real-estate pressure and the high benefits ripped off by the new entrepreneurs in this type of spaces, the social cohesiveness of the old central districts has been deeply affected: regional houses and sports \& cultural associations close, giving way to hotels and other residential products. The Casa dos Amigos do Minho and the Ateneu Comercial de Lisboa will be especially missed. The institutions that functioned as social gathering spots for Lisboners are disappearing in many neighbourhoods, while the theatralisation and marketability of "Lisbon's traditional essence" become overriding features of urban public life. Places and venues that represent, package and sell "Lisbon's experience" in assorted shapes and prices, are cropping up along every tourist route - from the ginginha (cherry liqueur) kiosks and the shops that sell the emblematic canned sardines, to the redesigned cafés and reinvented casas do fado ("fado houses"). Worthy of special mention is the city's most popular celebration, the Santos Populares festival in June. A festival that was once restricted to less than a week to celebrate Saint Anthony's day, it has now been extended to the whole month, attracting a growing presence of national and international tourists. Surely, the old-fashioned, carnival-like, maritime-inspired camp aesthetics of this celebration (be it the central parade where popular neighbourhoods compete for the annual prize or the all-night festivities in the old bairros) fits perfectly with the stereotyped idea of Portugal recreated during the Estado Novo regime and sold ever since by the tourist agencies: a nation made of people with brandos costumes ("mild manners"), warm-hearted, simple, home-loving, and averse to conflict and strident collective demonstrations (the inverse of the equally stereotyped version of their Spanish neighbours), deeply Catholic and conservative, impregnated by the pseudo-mysticism of the saudade ("fatalist longing"), and still whining about the legendary grandeur of a lost maritime empire.

As the official engagement with the project of selling out the country in a feverish and 
spiralling hunt for visitors continues, large tracts of the national budget are committed to the expansion of the old airport and the construction of a new one, the opening of the new cruise terminal, and the planning of a third bridge over the Tagus river; in the meanwhile, people wonder why the Government appeals for temperance and refuses to improve the perennially low salaries and the national health service. Similarly, legal incentives for real-estate market strategies keep being pursued in the form of deregulation and loosening of bureaucratic control, paired with the expected celebration of further mega-events (the latest hosted by the city was the Ibero-American Capital of Culture, in 2017). All these three vectors seem to confirm that the cycle of evictions, inflated rental prices and continued caricaturing of Lisbon will not abate in the next decade.

\section{FINAL THOUGHTS}

In a rare recent interview in RTP, the state-owned TV station, ${ }^{15}$ historian and one-time political commentator Vasco Pulido Valente elaborated on the mysterious case that is the almost total absence of far-right, xenophobic, racist, nationalist, anti-migrant movements in Portugal, all the more exceptional given how these are presently festering so many European countries' political divisions. For him, the almost millenary stability of Portugal's territorial borders is the grounding source of the homogeneity and the unquestionability of its national identity and hence of the lack of extremist positions, even considering that Lisbon has a history of being a cosmopolitan exception in the country. If we add to this factor the non-existence of regional languages, of ethnicity-based divides and a historically religious uniformity, we may find the means to circumscribe the Portuguese "anomaly". The strains under which Lisbonners are currently living due to the rapid changes described in this article haven't, at least until now, spilled into populist, xenophobic, anti-migrant or anti-tourist stances in the public discourse. There are occasional complaints in affected neighbourhoods against the noise drunken youngsters make at night, but there is no discrimination between national and foreign ones; people do complain against the rise in house-rents and evictions but they don't distinguish between internal and external speculators; asylum-seekers from war-torn countries are received with open arms by the national government only to endure the same fate of the Portuguese poor - either find precarious jobs or flee to richer European countries; Northern European retirees are welcomed to buy and rehabilitate old houses and flats since, much as the returning Portuguese migrants, they keep the house-building job market afloat; Madonna's desperate house-searches and her clashes with state bureaucracy read as an endearing caricature of the natives' own troubles; tourists asking for directions are

15. RTP 3, Grande Entrevista (XI), 20 Jun, 2018. URL: https://www.rtp.pt/play/p4258/e352683/ grande-entrevista, accessed 27/08/2018. 
treated as a free opportunity to exercise foreign language conversational skills; Brazilian and African migrants are conceived of as returning prodigal sons who have lost some linguistic abilities and perhaps the exactitude of the native moral compass.

This peculiar social atmosphere ought to serve as a reminder that when it comes to the study of touristified cities the specificities of each case shouldn't be overshadowed by generalising temptations but can best lead to a questioning attitude. Going back to Hardin's commons metaphor, we could ask the following: if neither the herders nor the herd complain against the scarcity of grazing land, must we still describe the situation as tragic? The overwhelming touristification of city centres around the world is being fuelled by a cocktail of conditions that include democratisation of travel, deregulation of temporary house-renting, easing of national controls, among others. Such processes have lately caused a flurry of unintended consequences with which national governments, local authorities and "native" dwellers are trying to grapple in diverse ways. But if we dig further, and search for inspiration in the words of Elinor Ostrom, a possibly more open and less pessimistic reading of contemporary urban touristification becomes thinkable. Ultimately, these urban processes are not excepcional occurrences that divert from the normal functioning of central cities but the hegemonic model of capitalism as expressed in its urban form. As a consequence, many antagonist social exchanges and unsuspected alternatives should be flourishing in parallel to what seems the plain triumph of neoliberalism in our urban social order. Who, indeed, are we to negatively judge the gentrification processes only by their negative consequences, foster fatalist views on geographic displacement and the attempt to paternalistically condemn the perceived misfortunes of a whole population? Such a cynical stance doesn't necessarily mean to evict any "critical perspectives from gentrification research" (Slater, 2006) but to challenge our common understanding about the complex interface (finance, social actors, imaginaries, states, associations, international law) that shapes current - and undoubtedly harmful for many - processes of urban change such as touristification and gentrification.

Also, and contrary to the likes of Nassim Nicholas Taleb, we wouldn't apriori deride "the tourist" as being but a puppet actor following a strict script, or describe touristification as an evil that:

Castrates systems and organisms that like uncertainty by sucking randomness out of them to the last drop - while providing them with the illusion of benefit. [...As] an aspect of modern life that treats humans as washing machines, with simplified mechanical responses and a detailed user's manual. [...And as] the systematic removal of uncertainty and randomness from things, trying to make matters highly predictable in their smallest details (Taleb, 2012: 67). 
Rather, we prefer to take a more nuanced view, grounded on attentive empirical research in order to break away from the self-serving intelectual trap that often corners the researcher into disingenuously lamenting the loss of authenticity of ancient urban centres and the disaggregation of closely knit communities, and into searching for an imaginary high-ground from where he/she snubs the artificiality of touristified urban landscapes. There is something of a sad paradox in such position inasmuch as the same academic who mourns and criticises is him/herself a (albeit minor) vehicle of the touristification and gentrification processes. Through his/her fieldwork, expertise, and parlance in international conferences, he/she surely adds to the carbon footprint of international travel and the sustainability of the lodging and eatery industries (not to mention his/ her willing participation in binge drinking setups) - a gentrificator who criticises gentrification and a tourist who laments tourism seems to be in a logically untenable situation, making this a poor starting point for any coherent analysis into what makes a touristified city a common good, with all its structural problems and imbalances, and not simply a privatised fief, a flattened and de-characterised urban landscape. 


\section{REFERENCIAS BIBLIOGRÁFICAS}

Balula, L. (2010) "Espaço público e criatividade urbana. A dinâmica dos lugares em três bairros culturais". Cidades, Comunidades e Territórios 20-21, pp. 43-58.

Benson, M., and O'reilly, K. (2009) "Migration and the search for a better way of life: a critical exploration of lifestyle migration". The sociological review 57 (4), pp. 608-625.

Blumer, H. (1969) "The methodological position of symbolic interactionism". En H. Blumer (ed.) Symbolic Interactionism: Perspective and Method. Englewood Cliffs (NJ, USA): Prentice-Hall, pp. 1-60.

Borch, C., and Kornberger, M. (Eds.). (2015) Urban commons: Rethinking the city. Routledge.

Braga, I. (2013) "Bairro Alto. Uma história concentrada". O Corvo. Sítio de Lisboa. URL: https://ocorvo.pt/bairro-alto-uma-historia-concentrada/ [consultado el 21 de mayo de 2018]

Cabêdo S.; Carmo, M.; and Martins, H. (2003) "Traços nocturnos (Percursos juvenis na noite do Bairro Alto)". En José Machado Pais (ed.), Traços e Riscos de Vida. Uma abordagem qualitativa a modos de vida juvenis. Lisboa: Ambar, pp. 217-261.

Cabral, J. and Rato, B. (2005) "Urban development for competitiveness and cohesion: the Expo'98 urban project in Lisbon”. En Frank Moulaert, Arantxa Rodriguez y Erik Swyngedouw (eds.) The Globalized City: Economic Restructuring and Social Polarization in European Cities. Oxford University Press, pp. 209-228.

Capel, H. (2005) El modelo Barcelona: un examen crítico. Barcelona: Ediciones del Serbal. Carita, H. (1990) Bairro Alto Tipologias e Modos Arquitectónicos. Lisboa: Câmara Municipal de Lisboa.

Carmo R. M., Cachado R. and Ferreira D. (2015) Desigualdades em tempos de crise: Vulnerabilidades habitacionais e socioeconómicas na Área Metropolitana de Lisboa. Revista Portuguesa de Estudos Regionais 40, pp. 5-22.

Caulfield J. (1989) "Gentrification and desire". Canadian Review of Sociology and Anthropology, 26 (4), pp. 617-632.

Chatterton P and Hollands R. (2003) Urban Nightscapes: Youth Cultures, Pleasure Spaces and Corporate Power. London and New York: Routledge.

Cocola-Gant, A. (2018) “Tourism Gentrification”. En Lees, L and Phillips, M (Eds) Handbook of Gentrification Studies. Cheltenham and Northampton: Edward Elgar Publishing, pp. 281-293. 
Costa, P. (2013) Bairro Alto revisited: Reputation and symbolic assets as drivers for sustainable innovation in the city. (DINAMIA-CET Working Paper 2013/14). URL: http:// hdl.handle.net/10071/6634 [consultado el 18 de mayo de 2018]

Da Costa Holton, K. (2003) “Lisboa 94, Capital Europeia da Cultura”. En Salwa CasteloBranco y Jorge Freitas Branco (eds.) Vozes do Povo: A Folclorização em Portugal. Oeiras: Celta Editora.

Dawes, R. M. (1973) “The Commons Dilemma Game: An N-Person Mixed-Motive Game with a Dominating Strategy for Defection". ORI Research Bulletin, 13, pp. 1-12.

Delgado, M. (2007). La ciudad mentirosa. Fraude y miseria del "modelo Barcelona". Madrid: Los libros de la Catarata.

Ferreira, V. M. (2004) Fascínio da cidade. Memória e projecto da urbanidade. Centro de Estudos Territoriais (ISCTE). Lisboa: Ler Devagar.

Ferreira, C. C. (2006) A Expo'98 e os imaginários do Portugal contemporâneo: cultura, celebração e políticas de representação. Coimbra: Faculdade de Economia da Universidade de Coimbra (Tese de Doutoramento).

Ferreira Costa, B. and Teles, G. (2017) A Política de Acolhimento de Refugiados Considerações sobre o caso português. REMHU, Revista Interdisciplinar da Mobilidade Humana, 25 (51), pp. 29-46.

Gato, M. A. (2014) Viver no Parque das Nações: espaços, consumos e identidades. Lisboa: Imprensa de Ciências Sociais.

Gines, R. (2018) "A Portuguese Crusader Seeks to Tap the Brakes on Golden Visas. Gold for Visas". URL: https://www.occrp.org/en/goldforvisas/a-portuguese-crusader-seeksto-tap-the-brakes-on-golden-visas [consultado el 25 de mayo de 2018]

Gotham K. F. (2005) “Tourism gentrification: The case of New Orleans' Vieux Carre (French Quarter)". Urban Studies 42, (7), pp. 1099-1121.

Hammersley, M. and Atkinson, P. (2007) Ethnography: Principles in practice. Routledge. Hardin, G. (1968) “The Tragedy of the Commons”. Science 162, pp. 1243-8.

Harvey D. (1989) "From managerialism to entrepreneurialism: The transformation in urban governance in late capitalism". Geografiska Annaler. Series B. Human Geography, 17 (1), pp. 3-17.

Janoschka M., Sequera J. and Salinas L. (2014) "Gentrification in Spain and Latin America - A critical dialogue". International Journal of Urban and Regional Research, 38 (4), pp. $1234-1265$. 
Janoschka, M.; Haas, H. (eds) Contested Spatialities, Lifestyle migration and Residential Tourism. London: Routledge

Ingold, T. (2007) Lines: A Brief History. London: Routledge.

Ingold, T. (2013) Making: Anthropology, Archaeology, Art and Architecture. London: Routledge.

Lees, L., Slater, T., and Wyly, E. (2013) Gentrification. London: Routledge.

Ley, D. (2003) "Artists, aestheticisation and the field of gentrification". Urban Studies, 40 (12), pp. 2527-2544.

Lofland, J. and Lofland, L. (1995) Analyzing social settings: A guide to qualitative observation and analysis. Belmont (CA, USA): Wadsworth.

Madeira, C.A. (2009) A Reabilitação Habitacional em Portugal - Avaliação dos Programas RECRIA, REHABITA, RECRIPH E SOLARH. Lisboa: Faculdade de Arquitectura, Universidade Técnica de Lisboa (Master Thesis).

Marques Durão, V.C. (2011) “Megaeventos em Portugal: Expo’98 e Euro 2004. Análise do pós-evento”. Urbe. Revista Brasileira de Gestão Urbana 3 (2), pp. 229-243.

Mendes, L. (2017) "Gentrificação turística em Lisboa: neoliberalismo, financeirização e urbanismo austeritário em tempos de pós-crise capitalista 2008-2009”. Cadernos Metrópole 19 (39), pp. 479-512.

Olson, M. (1965). The Logic of Collective Action, Public Goods and the Theory of Groups. Cambridge, Mass.: Harvard University Press.

Pavel, F. (2014) "Architecture and society in Bairro Alto: Prostitutes, artists and stabbings; palazzi, streets and alleys". En Lénia Marques y Greg Richards (eds.) Creative districts around the world. Celebrating the 500th anniversary of Bairro Alto. Breda: University of Applied Sciences, pp. 09-16.

Portelinha, R. (2009) A dimensão cultural da integração europeia. Capitais Europeias da Cultura. Coimbra: Faculdade de Letras da Universidade de Coimbra (Tese de Mestrado). Power, M. and Sidaway, J. D. (2005) "Deconstructing twinned towers: Lisbon's Expo'98 and the occluded geographies of discovery". Social \& Cultural Geography, 6 (6), pp. 865883.

Radcliffe-Brown, A.R. (1965) [1952] Structure and Function in Primitive Society. Essays and Addresses. New York \& London: The Free Press.

Roche, M. (1992) "Mega-Events and Micro-Modernization: On the Sociology of the New Urban Tourism”. The British Journal of Sociology, 43 (4), pp. 563-600. 
Rodrigues, W. (2010) "Cidade em Transição. Nobilitação Urbana, Estilos de Vida e Reurbanização em Lisboa”. Oeiras: Celta Editora.

Rogers, D. (2017) Geopolitics of Real Estate: Reconfiguring Property, Capital, and Rights. London and New York: Rowman and Littlefield.

Rose D. (1984) "Rethinking gentrification: Beyond the uneven development of marxist urban theory". Environment and Planning D 1, pp. 47-74.

Santos, M. G. M. P (2000) “Da Expo'98 ao Euro 2004: notas para o estudo do impacto de grandes eventos no turismo regional”. Educação \& Comunicação 4, pp. 22-47.

Scott A. J. (2014) "Beyond the creative city: Cognitive-cultural capitalism and the new urbanism”. Regional Studies, 48 (4), pp. 565-578.

Slater, Tom (2017) “Planetary rent gaps”. Antipode 49 (S1), pp. 114-137.

Taleb, Nassim Nicholas (2012) Antifragile: Things that Gain from Disorder. New York: Random House.

Torkington, K.; Sardinha, J.; and David, I. (eds) Practising the Good Life: Lifestyle Migration in Practices. Cambridge: Cambridge Scholars Publishing.

Tulumello, Simone (2016) "Reconsidering neoliberal urban planning in times of crisis: Urban regeneration policy in a 'dense' space in Lisbon'. Urban Geography, 37 (1), pp. 117-140.

Weber, R. (2010) "Selling City Futures: The Financialization of Urban Redevelopment Policy”. Economic Geography 86 (3), pp. 251-274. 